\title{
Penggunaan Novel Tetralogi Laskar Pelangi dalam Pengembangan Bahan Ajar Menulis Teks Deskripsi untuk Siswa SMP Kelas VII
}

\author{
Khairun Nisa Maksum ${ }^{1}$, Dawud ${ }^{1}$, Suyono ${ }^{1}$ \\ ${ }^{1}$ Pendidikan Bahasa Indonesia-Universitas Negeri Malang
}

\begin{tabular}{l} 
INFO ARTIKEL \\
\hline Riwayat Artikel: \\
Diterima: 03-03-2020 \\
Disetujui: $16-07-2020$ \\
\hline
\end{tabular}

\section{Kata kunci:}

laskar pelangi tetralogy; teaching materials; description text tetralogi laskar pelangi; bahan ajar; teks deskripsi

\begin{abstract}
ABSTRAK
Abstract: A novel is a literature work of fiction which tells about the life of a person and the people around him which are presented in a series of stories that are more complex. A novel can be used as a source of learning for students. This study uses a novel as the source of learning to develop teaching material. This study aims at producing teaching material which describes the setting, characters, and events being told in the novel. This study is a research and development study which uses a 4-D model. The model covers four main stages namely define, design, develop, and disseminate. The teaching material that has been compiled contains activities, steps, exercises, revisions, and peer-assessments in writing descriptive text about setting, characters, and events by using quotations written in the tetralogy of Laskar Pelangi. The activities, steps, and exercises in the teaching material will help the students in writing descriptive text well and detailed.

Abstrak: Novel merupakan karya fiksi dengan rangkaian cerita kehidupan seseorang dengan orang lain di sekelilingnya yang ditampilkan lebih kompleks. Novel dapat digunakan sebagai sumber belajar bagi peserta didik. Penelitian ini menggunakan novel untuk mengembangkan bahan ajar sebagai sumber belajar peserta didik. Penelitian ini bertujuan untuk menghasilkan bahan ajar mendeskripsikan latar dalam novel, menghasilkan bahan ajar mendeskripsikan tokoh dalam novel, dan menghasilkan bahan ajar mendeskripsikan peristiwa dalam novel. Penelitian ini merupakan penelitian dan pengembangan dengan menggunakan model pengembangan 4-D, yaitu define (penetapan), design (perancangan), develop (pengembangan), dan disseminate (penyebaran). Bahan ajar yang telah disusun berisi kegiatan, langkah-langkah, latihan, revisi, dan penyuntingan teman sejawat dalam menulis teks deskripsi latar, tokoh, dan peristiwa dengan menggunakan kutipan-kutipan dari novel tetralogi Laskar Pelangi. Kegiatan, langkah-langkah, dan latihan dalam bahan ajar tersebut akan membantu peserta didik dalam menulis teks deskripsi yang baik, benar, dan terperinci.
\end{abstract}

\section{Alamat Korespondensi:}

Khairun Nisa Maksum

Pendidikan Bahasa Indonesia

Universitas Negeri Malang

Jalan Semarang 5 Malang 65145

E-mail: dinceavia@gmail.com
Novel merupakan karya sastra yang bersifat fiksi. Novel berfungsi sebagai sarana untuk menuangkan suatu gagasan, ide, dan perasaan penulis sebagai upaya menceritakan kehidupan di sekitarnya. Masalah yang muncul dari masyarakat akan diubah oleh seorang penulis menjadi sebuah cerita yang menarik. Novel dapat dikemukakan secara bebas, disajikan dengan konflik yang lebih kompleks, tokoh dan latar yang lebih detail jika dibandingkan dengan cerita pendek (Salfia, 2015). Novel dibangun oleh unsur intrinsik dan unsur ekstrinsik. Unsur instrinsik adalah unsur-unsur yang membangun karya sastra itu sendiri, yaitu tema, latar, tokoh, alur, amanat, sudut pandang, dan gaya bahasa. Unsur ekstrinsik adalah unsur yang berada di luar karya satra itu, tetapi secara tidak langsung memengaruhi karya sastra, seperti keadaan subjektivitas individu pengarang yang mempunyai sikap, keyakinan, dan pandangan hidup. Novel tidak hanya digunakan sebagai bacaan yang bertujuan untuk hiburan semata, tetapi dapat dimanfaatkan sebagai media, sumber, dan sarana untuk peserta didik dalam proses pembelajaran. Membaca dan menggunakan novel dalam pembelajaran sangatlah bermanfaat untuk siswa. Siswa dapat mengetahui dan mempelajari nilainilai kehidupan, cita-cita budaya, keragaman agama, kebiasaan, dan tradisi yang berbeda dengan lingkungan dan budaya peserta didik melalui imajinasi seseorang yang dituangkan dalam percakapan antar tokoh dan konflik yang kompleks yang dikemas secara menarik oleh penulis (Balmer, 2018). 
Salah satu novel yang dapat dimanfaatkan sebagai media, sumber, dan sarana untuk siswa adalah novel tetralogi Laskar Pelangi karya Andrea Hirata. Novel tetralogi Laskar Pelangi terdiri dari empat buku, yaitu Laskar Pelangi, Sang Pemimpi, Edensor, dan Maryamah Karpov. Novel Laskar Pelangi terbit pertama pada bulan September 2005, setelah Laskar Pelangi, kelanjutan tetraloginya adalah Sang Pemimpi diterbitkan pada tahun 2006 oleh Yayasan Bentang Yogyakarta, Edensor diterbitkan pada tahun 2007, dan Maryam Karpov yang diterbitkan pada bulan November tahun 2008 di Jakarta. Novel tetralogi Laskar Pelangi ini bercerita tentang semangat dan perjuangan hidup dalam mendapatkan pendidikan yang layak dan mengejar mimpi-mimpi untuk memwujudkannya di balik hidup dalam kemiskinan yang menghantui. Novel tersebut dapat digunakan sebagai pengetahuan awal siswa mengenal dunia sastra sejak dini karena karya sastra Andrean Hirata tidaklah sulit untuk dipahami bagi peserta didik. Salah satu cara dalam penggunaan novel sebagai sumber belajar dengan memanfaatkan novel sebagai sumber dalam mengembangkan bahan ajar.

Bahan ajar berfungsi sebagai wujud dari penjelasan pendidik di depan kelas. salah satu proses pengembangan yang inovasi dalam pendidikan adalah dengan mengembangkan dan menyusun bahan ajar. Pengembangan bahan ajar berawal dari konvensional menuju inovatif yang dapat membantu guru dan peserta didik dalam proses belajar sehingga proses pembelajaran tersebut lebih menyenangkan dan tidak membosankan dengan agar berbagai tema yang beragam (Widodo, 2017). Bahan ajar disusun tidak hanya dengan konsep dan fakta yang hanya akan diingat oleh pelajar, tetapi bahan ajar harus dapat membantu dan dimanfaatkan oleh pelajar dalam membangun dan mengonsep pengetahuan berdasarkan makna yang diperoleh dari pengalaman yang nyata. Pengalaman belajar dibentuk dari penataan kegiatan belajar yang kaya dengan berbagai variasi sehingga peserta didik akan lebih aktif dan efektif dalam mencapai tujuan pembelajaran (Wulandari, Rosiana, \& Abidin, 2019). Penyusunan bahan ajar memiliki tujuan, yaitu (1) siswa dapat mempelajari sesuatu yang baru, (2) tersedianya buku pelajaran dengan berbagai pilihan tema, (3) membantu guru dalam proses pengajaran, dan (4) supaya proses pembelajatan tidak membosankan (Atmazaki, Afnita, \& Zuve, 2016). Dengan demikian, bahan ajar yang disusun dengan kreatif dan inovatif yang disesuaikan dengan kurikulum yang digunakan, kebutuhan siswa, sekolah, dan daerah akan menjadi bahan ajar yang berkualitas yang memiliki konstribusi yang besar terhadap proses pembelajaran, tidak terkecuali dalam pembelajaran keterampilan berbahasa.

Salah satu keterampilan berbahasa yang paling sukar adalah keterampilan menulis. Menulis merupakan ekspresi yang ditampikan setiap individu untuk menggambarkan dirinya (Durukan, 2011). Menulis berfungsi sebagai alat komunikasi yang tidak langsung dengan melukiskan lambang-lambang grafis suatu bahasa yang dipahami oleh seseorang (Rasmianti, Bukhari, \& Yamin, 2017). Menulis merupakan proses yang kompleks, proses tersebut dikembangkan dengan kemampuan berpikir dinamis, kemampuan analitis, dan kemampuan membedakan berbagai hal secara akurat dan valid. Menulis tidak hanya berfungsi untuk menggambarkan sesuatu yang telah diketahui, tetapi menulis merupakan cara untuk memahami suatu hal tersebut (Nasution, 2017). Menulis adalah penemuan makna, pengembangan ide atau konten, proses yang sistematis yang dapat dibagi menjadi beberapa langkah atau tahapan misalnya, prapenulisan, penyusunan, umpan balik, revisi, dan mengedit (Atkinson, 2018). (Kristyanawati, Suwandi, \& Rohmadi, 2019) menjelaskan langkah-langkah menulis terdiri dari (1) mengemukakan ide, (2) menulis secara garis beasar, (3) membuat draf atau kerangka, dan (4) merevisi dan menyunting. Kegiatan keterampilan menulis di sekolah bertujuan untuk menilai pengetahuan siswa tentang materi yang disajikan di kelas, siswa akan terlebih dahulu menulis kalimat sederhana dan kompleks, kemudian berkembang menjadi sebuah paragraf dan hasil akhirnya akan menjadi wacana. Kemajuan perkembangan menulis peserta didik dapat dilatih dengan menumbuhkan cinta dan kesukaan terhadap minat menulis (Graham, 2018). Dengan demikian, keterampilan menulis bukanlah hal yang mudah, tetapi dilakukan dengan beberapa tahap dan dikembangkan melalui latihan merangkai gagasan dan ide sehingga menjadi tulisan yang utuh.

Kompetensi dasar mata pelajaran Bahasa Indonesia dalam kurikulum 2013 untuk subaspek menulis SMP kelas VII salah satunya, yaitu menciptakan kembali teks deskripsi dengan memerhatikan struktur dan kebahasaan. Menulis teks deskripsi merupakan bentuk komunikasi yang dilakukan secara tidak langsung dengan tulisan yang lebih menekankan pada ekspresi diri, emosi, gagasan, dan ide yang didukung oleh pengetahuan, pengamatan, kebahasaan dan teknik penulisan (Lestari, 2017). Sementara itu, Sitohang, Syahfitri, \& Siburian (2019) menjelaskan teks deskripsi merupakan teks yang mendeskripsikan suatu objek yang sudah ditentukan sebagai salah satu sarana dengan potensi yang tinggi dalam melatih pengetahuan kita. Selanjutnya, Sari (2018) menyatakan bahwa teks deskripsi merupakan teks yang memberikan, melukiskan, atau menggambarkan suatu hal sedemikian rupa sehingga objek itu seolah-olah berada di depan mata pembaca dan seakan-akan pembaca melihat objek itu. Keterampilan menulis teks deskripsi merupakan salah satu dasar keterampilan menulis yang mengharuskan peserta didik untuk dapat mengepresikan ide atau perasaan kepada pembaca sehingga pembaca dapat memahami dan pembaca seolah dekat dan melihat objek yang diuraikan oleh penulis. Untuk menghasilkan teks yang tepat, peserta didik harus dapat memerhatikan struktur yang berkaitan dengan teks deskripsi tersebut, yaitu identifikasi, deskripsi, dan simpulan. Teks deskripsi akan lebih mudah disusun dan dipahami jika memahami strukturnya (Saddhono, et al., 2018).

Pada dasarnya dalam proses pengajaran menulis teks deskripsi, siswa tidak sekedar mendapatkan teori tentang menulis teks deskripsi, tetapi siswa diharuskan untuk mempraktikkan teori-teori yang telah didapatkannya dengan menghasilkan teks deskripsi sehingga tujuan pembelajaran tercapai. Akan tetapi, kemampuan siswa dalam menulis teks deskripsi masih tergolong rendah. Hal ini disebabkan oleh pengetahuan siswa tentang teks deskripsi masih rendah, penggunaan kosa kata yang terbatas, keterbatasan menentukan topik, kurangnya ilustrasi dalam kehidupan sehari-hari, penggunaan struktur dan ejaan yang kurang tepat, serta penggunaan bahan ajar yang hanya menggunakan buku ajar dari pemerintah dan tidak ada bahan ajar penunjang sebagai alternatif dalam menulis teks deskripsi. Bahan ajar penunjang diperlukan oleh pendidik dalam proses pengajaran yang 
bertujuan sebagai pelengkap materi yang ada dalam bahan ajar dari pemerintah. Oleh karena itu, peneliti mengembangkan bahan ajar menulis teks deskripsi dengan sumber novel tetralogi Laskar Pelangi karya Andrea Hirata.

Dalam novel tetralogi Laskar Pelangi peserta didik akan dapat menemukan teks deskripsi yang baik dan benar terutama dalam mendeskripsian latar, tokoh dan peristiwa. Andrea Hirata dalam mendeskripsikan latar, seperti latar sekolah SD Muhammadiyah, sekolah PN Timah, menara Eiffel, perpustakaan dan lain-lain sangat jelas dan terperinci dimulai dari mendeskripsikan bentuk atau wujudnya, suasana, waktu, tata letak benda, dan tata letak tempat yang ada di sekitar bentuk atau wujud tersebut. Sementara itu, untuk mendeskripsikan tokoh dalam novel tersebut, seperti tokoh Ikal, Lintang, Arai, Pak Belia, Sahara, dan lain-lain, Andrea Hirata mendeskripsikan mulai dari perincian fisik tokoh, watak tokoh, bakat, dan peran tokoh dalam novel tersebut. Begitu pula dalam mendeskripsikan peristiwa, seperti peristiwa 17 Agustus, kegiatan Chiong Si Ku, keadaan dermaga olivir dan lain-lain akan dideskripsikan dengan sangat jelas dan terperinci dimulai dengan menyebutkan rincian kegiatan, tokoh, suasana, waktu, konflik, dan solusi dalam peristiwa tersebut. Penelitian pengembangan ini memiliki tiga tujuan, yaitu (1) menghasilkan bahan ajar mendeskripsikan latar dalam novel, (2) menghasilkan bahan ajar mendeskripsikan tokoh dalam novel, dan (3) menghasilkan bahan ajar mendeskripsikan peristiwa dalam novel.

\section{METODE}

Penelitian pengembangan ini menggunakan teknik analisis data kualitatif dan teknik analisis data kuantitatif. Analisis kualitatif digunakan untuk menganalisis data verbal, analisis dilakukan terhadap kegiatan hasil wawancara terhadap guru pada pengumpulan data awal, komentar, kritikan, dan saran yang tertulis didalam angket validasi subjek ahli dan subjek praktisi yang berupa data verbal. Data verbal yang diperoleh dikumpukan dan ditranskip yang dikelompokkan dalam kriteria tertentu. Teknik analisis data kuantitatif digunakan untuk data numerik yang diperoleh dari hasil uji validasi ahli dan uji lapangan kecil. Teknik analisis data kuantitatif juga digunakan untuk menguji keefektifan produk, uji keefektifan produk dilakukan untuk mengukur apakah produk bahan ajar yang dikembangkan memberi dampak signifikan bagi keterampilan menulis teks deskripsi peserta didik atau tidak. Uji keefektifan produk dilakukan dengan dua tahap, yaitu uji normalitas data dan uji beda.

Sumber data penelitian pengembangan ini terdiri dari dua sumber data, yaitu sumber data subjek dan sumber data objek. Sumber data subjek terdiri dari (1) subjek ahli adalah ahli bahan ajar dan ahli materi dan bahasa, (2) subjek praktisi adalah guru bahasa Indonesia SMP yang telah memiliki pengalaman mengajar minimal lima tahun, serta (3) subjek lapangan adalah peserta didik kelas VII-C SMP Negeri 1 Bangil yang berjumlah 30 siswa. Sumber data objek berupa tulisan peserta didik kelas VII-C SMP Negeri 1 Bangil yang merupakan hasil menulis teks deskripsi.

Prosedur penelitian pengembangan yang digunakan adalah pengembangan model 4-D, yaitu define (penetapan), design (perancangan), develop (pengembangan) dan disseminate (penyebaran) (Trianto, 2015). Pertama, tahap penetapan, dilakukan secara bertahap, yaitu (1) analisis awal, analisis ini dilakukan dengan melihat kurikulum yang digunakan di sekolah dan dilakukan wawancara dengan guru mata pelajaran bahasa Indonesia untuk mengonfirmasi tentang isu-isu yang telah ditemukan sebelumnya, (2) analisis peserta didik, analisis karakteristik peserta didik dilakukan dengan observasi dan penyebaran angket pada peserta didik kelas VII-3 SMP, kegiatan ini dimaksudkan agar dapat diketahui apa saja kesulitan-kesulitan peserta didik dalam pembelajaran teks deskripsi dan juga bahan ajar yang dibutuhkan dan diinginkan untuk menunjang pembelajaran teks deskripsi, dan (3) menelaah buku teks, telaah buku teks khususnya pembelajaran terhadap materi teks deskripsi kelas VII yang disusun oleh Kemendikbud merupakan acuan untuk mengembangkan bahan ajar teks deskripsi.

Kedua, tahap perencanaan, terdiri dari dua tahap, yaitu (1) pengumpulan materi bahan ajar, pada tahap ini peneliti memilih dan memilah kutipan-kutipan dalam novel tetralogi Laskar Pelangi untuk dimasukkan ke dalam kategori yang telah ditentukan dalam spesifikasi produk, yaitu (a) mendeskripsikan latar, (b) mendeskripsikan tokoh, dan (c) mendeskripsikan peristiwa, serta (2) pengonsepan bahan ajar, pada tahap ini konsep bahan ajar dirancang menjadi tiga bagian utama, yaitu: bagian awal, bagian inti, dan bagian akhir. Bagian awal berisi sampul, kata pengantar, daftar isi, petunjuk penggunaan buku, kompetensi dasar dan pembuka unit. Bagian inti merupakan bagian esensial yang memuat materi, kegiatan, dan latihan-latihan dalam pembelajaran teks deskripsi. Bagian inti menyajikan materi dari KI 3 (pemahaman) dan KI 4 (keterampilan) pada materi teks deskripsi. Bagian inti ini dibagi menjadi tiga unit, yaitu (a) unit 1: mendeskripsikan latar dalam novel, (b) unit 2: mendeskripsikan tokoh dalam dalam novel, dan (c) unit 3: mendeskripsikan peristiwa dalam novel. Bagian akhir memuat senarai pustaka, riwayat penulis, serta sampul belakang buku. Selanjutnya, ketiga bagian tersebut dirancang format desain, tataletak, tatawarna, dan aspek-aspek teknis lainnya.

Ketiga, tahap pengembangan produk, tahap ini terdiri dari tiga tahap, yaitu (1) tahap penyusunan bahan ajar, pada tahap ini dilakukan kegiatan, yaitu (a) materi bahan ajar yang telah dikumpulkan, kemudian diolah untuk menjadi acuan sebagai konsep dan materi dalam produk bahan ajar tersebut, (b) penyusunan berbagai kegiatan dan latihan sebagai anak tangga untuk mencapai tujuan pembelajaran, latihan-latihan tersebut menggunakan latihan-latihan konseptual (pemahaman) dan tes mengarang/menulis teks deskripsi, serta (c) penyusunan materi, kegiatan, dan latihan dalam produk bahan ajar harus sesuai dengan spesifikasi produk yang telah dikukuhkan sebagai acuan, (2) uji kelayakan, untuk menghasilkan bahan ajar menulis teks deskripsi dengan sumber novel tetralogi Laskar Pelangi yang baik dan benar dilakukan uji kelayakan produk yang dilakukan oleh validasi ahli dan praktisi, hasil dari validasi akan direvisi sesuai dengan penilaian, saran, dan kritik dengan tujuan untuk menyempurnakan produk dari bahan ajar yang telah dibuat, serta (3) revisi produk, dilakukan berdasarkan penilaian, saran, dan 
kritik yang diberikan oleh ahli dan praktisi pada saat dilakukan uji kelayakan dengan empat aspek yang perlu perbaikan, yaitu aspek isi, aspek penyajian, aspek bahasa, dan aspek tampilan.

Keempat, tahap pengujian produk. Tahap pengujian produk ini dilakukan pada uji coba lapangan yang diuji cobakan pada kelas VII-C SMP Negeri 1 Bangil untuk mengetahui tingkat keefektifan bahan ajar menulis teks deskripsi dengan sumber novel tetralogi Laskar Pelangi. Desain yang digunakan untuk mengukur keefektifan produk yang telah dikembangkan adalah desain praeksperimen yang terdiri dari dua kegiatan, yaitu pretes dan postes pada kelompok tunggal (tanpa kelas kontrol) yang dilakukan pada 30 peserta didik dalam satu kelas. Data pretes dan postes kemudian dianalisis melalui uji normalitas dan uji beda. Uji normalitas data pretes dan postes pada penelitian ini menggunakan teknik one-sample kolmogorof-smirnov test, hasil uji normalitas kemampuan menulis teks deskripsi siswa diketahui bahwa hasil uji Kolmgorov-Smirnov data pretes sebesar 0,008 dan hasil uji normalitas pada postes sebesar 0,010. Persebaran dikatakan normal jika hasil uji normalitas lebih besar dari 0,05. Hasil perhitungan data pretes dan postes lebih besar dari 0,05 sehingga distribusi normal. Selanjutnya, uji beda penelitian ini menggunakan teknik paired sampled t-test, diketahui perbedaan mean pretes sebesar 73,83 dan mean postes 79,83 dengan jumlah sampel 30 peserta didik. Standar deviation rata-rata dari sampel pretes sebesar 3,395 dan standar deviasi sampel postes sebesar 4,044. Hasil kolerasi perbedaan hasil pretes dan postes dari 30 siswa sebesar 865. Diketahui nilai signifikansi (2-tailed) $<0,05$ sehingga terdapat perbedaan antara data pretes dan postes. Dengan demikian, dapat disimpulkan bahwa terdapat perbedaan yang signifikan pada kemampuan menulis teks deskripsi sebelum dan sesudah menggunakan bahan ajar yang dikembangkan. Oleh karena itu, bahan ajar menulis teks deskripsi dengan sumber novel tetralogi Laskar Pelangi dapat diimplementasikan.

Kelima, tahap penyebaran, tahap ini dilakukan setelah melakukan penyempurnaan produk akhir. Produk yang telah direvisi setelah uji coba lapangan diproduksi sesuai dengan banyaknya permintaan dari pihak sekolah tempat pelaksanaan uji coba lapangan. Pada tahap ini peneliti telah memproduksi bahan ajar menulis teks deskripsi dengan menggunakan sumber tetralogi Laskar Pelangi sesuai dengan permintaan dari pihak sekolah tempat pelaksanaan uji coba lapangan.

\section{HASIL DAN PEMBAHASAN}

Bahan ajar menulis teks deskripsi dengan sumber novel tetralogi Laskar Pelangi terdiri dari tiga unit, yaitu (1) mendeskripsikan latar dalam novel, (2) mendeskripsikan tokoh dalam novel, dan (3) mendeskripsikan peristiwa dalam novel. Setiap unit terdiri dari materi, kegiatan, dan latihan yang dilengkapi dengan kutipan novel tetralogi LaskarPelangi yang akan menuntun siswa dalam menulis karangan deskripsi secara terperinci, baik dan benar. Setiap unit akan dipaparkan sebagai berikut.

\section{Mendeskripsikan Latar dalam Novel}

Unit I dalam Bahasa Indonesia: Bahan Ajar Menulis Teks Deskripsi dengan Sumber Novel Tetralogi Laskar Pelangi adalah mendeskripsikan latar dalam novel, peserta didik akan belajar untuk mengetahui dan memahami teks deskripsi latar dengan menggunakan novel tetralogi Laskar Pelangi yang di dalamnya terbagi menjadi beberapa bagian, yaitu (1) bagain I membaca teks deskripsi latar dalam novel, (2) bagian II menulis teks deskripsi latar, dan (3) bagian III merevisi teks deskripsi latar dalam novel. Pada setiap bagian, kegiatan dan latihan akan dilengkapi dengan kutipan novel tetralogi Laskar Pelangi.

Bagian I membaca teks deskripsi latar dalam novel ini, bertujuan untuk membangun dan membentuk konsep dasar peserta didik tentang teks deskripsi latar dengan membaca kutipan novel tetralogi Laskar Pelangi yang menunjukkan teks deskripsi latar. Perfetti \& Stafura (2014) menjelaskan bahwa kerangka sistem membaca, yaitu (1) pengetahuan bahasa atau linguistic, pengetahuan ortografi, dan pengetahuan secara umum merupaka tiga pengetahua yang digunakan dalam keterampilan memebaca, (2) proses membaca dimulai dari decoding, identifikasi kata, pengambilan makna, membangun konstituen, menyimpulkan dan pemahaman, serta (3) proses membaca tersebut akan diproses dalam sistem kognitif yang memiliki jalur proses seperti sistem memori perceptual, memori jangka panjang, dan sumber daya pemprosesan yang terbatas. (Maryani, Ichsan, \& Khairunnisa, 2017) berpendapat bahwa keterampilan membaca adalh suatu aktivitas yang bertujuan mendapatkan informasi yang dituangkan dalam tulisan. Bagian I dilengkapi dengan dua kegiatan, yaitu (1) membaca pemahaman untuk menentukan isi, peserta didik akan dituntun untuk membaca kutipan novel tetralogi Laskar Pelangi, kemudian peserta didik akan mengerjakan latihan untuk menguji pemahaman peserta didik terkait isi dari kutipan novel tersebut dengan menjawab benar atau salah dari pernyataan yang telah disediakan, dan (2) membaca pemahaman untuk mengenali kalimat utama dan kalimat penjelas, peserta didik akan membaca kutipan novel, kemudian mengerjakan latihan untuk menguji pemahaman peserta didik dengan memberikan tanda centang pada pernyataan yang mana termasuk kalimat utama dan kalimat penjelas pada kolom tabel yang telah disediakan. (Syafi'ie dalam Somadayo, 2011) mengemukakan bahwa membaca merupakan proses untuk membangun pemahaman terkait isi dari wacana tulis tersebut, dengan menggabungkan skemata pengetahuan dan pengalaman yang dimiliki akan memudahkan peserta didik untuk membentuk pemahaman dari wacana tersebut.

Bagian II dalam unit I ini adalah menulis teks deskripsi latar, peserta didik akan belajar memahami dan mengetahui cara menulis teks deskripsi latar yang baik dan benar dengan menggunakan sumber novel tetralogi Laskar Pelangi. Tarigan (2013) berpendapat bahwa menulis merupakan melukiskan lambang-lambang grafik suatu bahasa yang dimengerti oleh seseorang sehingga pembaca dapat mengetahui informasi dari tulisan tersebut. Bagian II ini peserta didik tidak langsung ditugaskan untuk menulis teks deskripsi latar, tetapi harus mengerjakan tiga kegiatan dan beberapa latihan yang menyertai 
kegiatan tersebut, yaitu (1) kegiatan I mendeskripsikan bentuk atau wujud, peserta didik belajar memahami dan mengetahui cara mendeskripsikan bentuk atau wujud dengan memerhatikan nama bentuk atau wujud serta menyebutkan tata letak benda dan tata letak tempat yang ada di sekitar bentuk atau wujud tersebut, (2) kegiatan II mendeskripsikan suasana objek dan waktu, peserta didik akan belajar memahami dan mengetahui cara mendeskripsikan suasana objek dan waktu, dan (3) kegiatan III menulis teks deskripsi latar, siswa akan menulis karangan deskripsi latar secara utuh dengan memerhatikan deskripsi bentuk atau wujud, suasana objek dan waktu. Yanti (2015) menyatakan bahwa latar merupakan tempat, suasana, dan waktu terjadinya konflik dalam cerita, meskipun latar dalam karya sastra tidaklah sepenuhnya sama dengan realitas tetapi latar yang diciptakan oleh seorang pengarang berdasarkan pengalaman dan pengamatan terhadap masyarakat dan lingkungan. Adapun jenis-jenis latar, yaitu (1) latar tempat menunjukkan di mana tempat peristiwa tersebut terjadi, (2) latar suasana adalah latar yang menunjukkan bagaimana situasi cerita terjadi, dan (3) latar waktu menunjukkan kapan cerita terjadi, misalnya sekarang, saat ini, pagi hari dll. Setiap kegiatan akan diawali dengan penjelasan singkat yang berkaitan dengan judul kegiatan tersebut. Setelah penjelasan singkat tersebut, dilanjutkan dengan penyajian contoh kutipan novel yang disertai dengan tanda-tanda di sekitar kutipan novel sebagai acuan menelaah perincian teks deskripsi latar. Setelah penyajian contoh dalam setiap kegiatan, dilanjutkan dengan penyajian latihan. Latihan-latihan yang diberikan tidak terlepas dari materi yang disajikan dari setiap kegiatan.

Bagian III dalam unit I ini merevisi teks deskripsi latar dalam novel, peserta didik akan belajar merevisi penulisan yang salah yang terdapat dari kutipan novel tetralogi Laskar Pelangi sehingga peserta didik dapat menulis dengan baik dan benar sesuai dengan ketentuan ejaan yang disempurnakan. Bagian III ini terdapat dua kegiatan yang harus dikerjakan oleh peserta didik, yaitu (1) merevisi penggunaan kata awalan dan kata depan teks deskripsi latar, peserta didik akan dituntun membaca dan memerhatikan penulisan kata awalan dan kata depan dari kutipan novel, kemudian mendata kesalahan penulisan kata awalan dan kata depan yang ditemukan dari kutipan novel tersebut pada tabel yang telah disediakan, dan (2) penyuntingan teman sejawat untuk menyempurnakan teks deskripsi latar, kegiatan ini dilakukan dengan menukarkan hasil menulis teks deskripsi latar dengan teman sebangku, kemudian peserta didik akan menilai hasil teks deskripsi temannya sesuai dengan rubrik yang telah disediakan. Peserta didik juga ditugaskan memberikan saran dan kritik terhadap hasil teks deskripsi latar temannya untuk menyempurnakan teks deskripsi latar tersebut. Rosidi (2009) menyatakan bahwa cirri-ciri tulisan yang baik, yaitu (1) keserasian antara judul dan isi, (2) penggunaan ejaan dan tanda baca yang benar dan tepat, (3) penulisan struktur kalimat yang benar dan tepat, serta (4) kelengkapan, kesenambungan, dan kesatuan setiap paragraf.

\section{Mendeskripsikan Tokoh dalam Novel}

Unit II dalam Bahasa Indonesia: Bahan Ajar Menulis Teks Deskripsi dengan Sumber Novel Tetralogi Laskar Pelangi adalah mendeskripsikan tokoh dalam novel, peserta didik akan belajar untuk mengetahui dan memahami teks deskripsi tokoh dengan menggunakan novel tetralogi Laskar Pelangi yang didalamnya terbagi menjadi beberapa bagian, yaitu (1) bagian I membaca teks deskripsi tokoh dalam novel, (2) bagian II menulis teks deskripsi tokoh, dan (3) bagian III merevisi teks deskripsi tokoh dalam novel. Pada setiap bagian, kegiatan dan latihan akan dilengkapi dengan kutipan novel tetralogi Laskar Pelangi.

Bagian I membaca teks deskripsi tokoh dalam novel ini, bertujuan untuk membangun dan membentuk konsep dasar peserta didik tentang teks deskripsi tokoh dengan membaca kutipan novel tetralogi Laskar Pelangi yang menunjukkan teks deskripsi tokoh. Terori konstruktivisme berpendapat bahwa peserta didik menghasilkan pengetahuan dan membentuk makna berdasarkan pengalaman mereka, peserta didik harus selalu aktif dalam membangun pengetahuan baru dari pengetahuan lama dan menerapkan pengetahuan itu pada situasi praktis, serta refleksi untuk membangun makna (John, 2018). Bagian I ini dilengkapi dengan dua kegiatan, yaitu (1) membaca pemahaman untuk menentukan isi, peserta didik akan mengerjakan latihan untuk menguji pemahaman peserta didik terkait isi dari kutipan novel tersebut dengan menjawab benar atau salah dari pernyataan yang telah disediakan, dan (2) membaca pemahaman untuk mengenali bentuk baku dan nonbaku, peserta didik akan dituntun untuk membaca kutipan novel dengan memerhatikan kata baku dan kata nonbaku yang digunakan, kemudian peserta didik akan mendata kata baku dan kata nonbaku yang ditemukan dari kutipan novel tersebut ke dalam kolom tabel yang telah disediakan.

Bagian II menulis teks deskripsi tokoh dalam novel ini bertujuan agar peserta didik dapat memahami dan mengetahui cara menulis teks deskripsi tokoh yang baik dan benar dengan menggunakan sumber novel tetralogi Laskar Pelangi sebagai contoh dan referensi dalam menulis teks deskripsi tokoh. Bagian II ini, peserta didik tidak ditugaskan untuk langsung menulis teks deskripsi tokoh tetapi peserta didik akan diarahkan dan dibimbing melalui kegiatan disertai dengan beberapa latihan yang disediakan untuk mengetahui perincian-perincian menulis teks deksripsi tokoh dengan baik dan benar. Kegiatan tahap-tahap menulis teks deskripsi tokoh dalam bagian II, yaitu (1) mendeskripsikan fisik tokoh, peserta didik akan belajar untuk mendeskripsikan fisik tokoh baik dari bentuk muka, warna kulit, postur tubuh, jenis rambut, warna rambut dll, (2) mendeskripsikan perincian watak tokoh, (3) mendeskripsikan perincian bakat dan peran tokoh, dan (4) menulis teks deskripsi tokoh, peserta didik akan menulis secara utuh teks deskripsi tokoh dengan memerhatikan perincian fisik tokoh, watak tokoh, peran dan bakat tokoh. Abrams dalam Nurgiyantoro (2012) menyatakan bahwa tokoh adalah mengemukakan bahwa tokoh pelaku yang memiliki sikap, sifat, tingkah laku, serta watak yang ditungakan kedalam dialog dan tindakan tokoh dalam cerita. Dalam mendeskripsikan tokoh, peserta didik haruslah terlebih dahulu mengetahui dan mengenal sosok tokoh yang akan dideskripsikan, maka peserta didik haruslah memiliki kemampuan atau interaksi sosial yang baik. Thi Yen Phuong (2018) 
mengatakan bahwa peserta didik menerima pengetahuan secara selektif dan bergantung pada kapasitas yang tersedia dengan menghubungkan apa yang mereka miliki dan apa yang mereka butuhkan untuk penerimaan mereka berdasarkan pengalaman individual dengan interaksi sosial, dimana pengetahuan merefleksikan dunia luar oleh, budaya, bahasa, keyakinan, interaksi dengan orang lain, pelajaran langsung, dan modeling. Setiap kegiatan akan diawali dengan penjelasan singkat yang berkaitan dengan judul kegiatan tersebut. Setelah penjelasan singkat tersebut, dilanjutkan dengan penyajian contoh kutipan novel yang disertai dengan tanda-tanda di sekitar kutipan novel sebagai acuan menelaah perincian teks deskripsi tokoh. Setelah penyajian contoh dalam setiap kegiatan, dilanjutkan dengan penyajian latihan. Latihan-latihan yang diberikan tidak terlepas dari materi yang disajikan dari setiap kegiatan.

Bagian III merevisi teks deskripsi tokoh dalam novel. Peserta didik akan belajar merevisi penulisan yang salah dari kutipan novel tetralogi Laskar Pelangi sehingga peserta didik dapat menulis dengan baik dan benar sesuai dengan ketentuan ejaan yang disempurnakan. Bagian III ini terdapat dua kegiatan yang harus dikerjakan oleh peserta didik, yaitu (1) merevisi penulisan huruf kapital teks deskripsi tokoh, peserta didik akan belajar mengetahui dan menggunakan penulisan huruf kapital yang baik dan benar dengan mendata kesalahan penulisan huruf kapital yang ditemukan dari kutipan novel pada kolom tabel yang telah disediakan, dan (2) penyuntingan teman sejawat untuk menyempurnakan teks deskripsi tokoh, kegiatan ini dilakukan dengan menukarkan hasil menulis teks deskripsi tokoh dengan teman sebangku, kemudian peserta didik akan menilai hasil teks deskripsi temannya sesuai dengan rubrik yang telah disediakan.

\section{Mendeskripsikan Peristiwa dalam Novel}

Unit III dalam Bahasa Indonesia:Bahan Ajar Menulis Teks Deskripsi dengan Sumber Novel Tetralogi Laskar Pelangi, yaitu mendeskripsikan peristiwa dalam novel, peserta didik akan belajar untuk mengetahui dan memahami teks deskripsi peristiwa dengan menggunakan novel tetralogi Laskar Pelangi yang di dalamnya terbagi menjadi beberapa bagian, yaitu (1) bagain I membaca teks deskripsi peristiwa dalam novel, (2) bagian II menulis teks deskripsi peristiwa, dan (3) bagian III merevisi teks deskripsi peristiwa dalam novel. Pada setiap bagian, kegiatan dan latihan akan dilengkapi dengan kutipan novel tetralogi Laskar Pelangi.

Bagian I membaca teks deskripsi peristiwa dalam novel bertujuan untuk membangun konteks dan pengetahuan awal peserta didik tentang teks deskripsi peristiwa dari kutipan novel tetralogi Laskar Pelangi yang telah disediakan. Dalam bagian ini terdapat dua kegiatan disertai dengan latihan yang harus dikerjakan, yaitu (1) membaca pemahaman untuk menentukan isi, peserta didik akan dituntun untuk membaca kutipan novel tetralogi Laskar Pelangi, kemudian peserta didik akan mengerjakan latihan untuk menguji pemahaman peserta didik terkait isi dari kutipan novel tersebut dengan menjawab benar atau salah dari pernyataan yang telah disediakan, dan (2) membaca untuk menceritakan kembali, peserta didik akan dibimbing untuk menceritakan kembali isi dari kutipan novel tersebut secara lisan. Kemampuan dalam menceritakan kembali merupakan proses mengonstruksi pengetahuan. Von Galserfeld dalam Pannen (2001) menyatakan bahwa untuk mengonstruksikan pengetahuan kemampuan yang diperlukan, yaitu (1) kemampuan untuk mengingat dan mengungkapkan kembali pengalaman, kemampuan untuk mengingat dan mengungkapkan pengalaman sangat penting karena pengetahuan dibentuk berdasarkan interaksi peserta didik dengan pengalaman tersebut, (2) kemampuan membandingkan dan mengambil keputusan akan kesamaan dan perbedaan suatu hal, dan (3) kemampuan untuk lebih menyukai suatu pengalaman yang satu daripada yang lain, melalui suka dan tidak suka inilah muncul penilaian bagi pembentukan pengetahuannya.

Bagian II menulis teks deskripsi peristiwa bertujuan agar peserta didik dapat menulis teks deskripsi dengan terperinci, baik, dan benar dengan memerhatikan beberapa perincian yang harus ada dalam mendeskripsikan peristiwa. Bagian II ini disertai beberapa kegiatan dan latihan yang harus dikerjakan yang merupakan suatu langkah-langkah dalam mendeskripsikan peristiwa, yaitu (1) mendeskripsikan perincian aktivitas suatu peristiwa, (2) mendeskripsikan perincian konflik dan solusi suatu peristiwa, dan (3) menulis teks deskripsi. Peristiwa adalah kejadian, hal, perkara, dan sebagainya yang sedang terjadi dan menarik perhatian. Dalam karya fiksi peristiwa berada pada unsur intrinsik alur sebagai pembangun karya fiksi tersebut. Aminuddin (2014) berpendapat bahwa alur merupakan peristiwa yang dihadirkan oleh tokoh sehingga membentuk suatu rangkaian cerita. Dalam peristiwa terdapat aktivitas, konflik, dan solusi yang didukung dengan unsur latar dan tokoh untuk menciptakan kejadian tersebut. Setiap kegiatan akan diawali dengan penjelasan singkat yang berkaitan dengan judul kegiatan tersebut. Setelah penjelasan singkat tersebut, dilanjutkan dengan penyajian contoh kutipan novel yang disertai dengan tandatanda di sekitar kutipan novel sebagai acuan menelaah perincian teks deskripsi tokoh. Setelah penyajian contoh dalam setiap kegiatan, dilanjutkan dengan penyajian latihan. Latihan-latihan yang diberikan tidak terlepas dari materi yang disajikan dari setiap kegiatan.

Bagian III merevisi teks deskripsi peristiwa dalam novel, peserta didik akan belajar merevisi penulisan yang salah yang terdapat dari kutipan novel tetralogi Laskar Pelangi sehingga peserta didik dapat menulis dengan benar sesuai dengan ketentuan ejaan yang disempurnakan. Dalam bagian tiga ini terdapat dua kegiatan yang harus dikerjakan oleh peserta didik, yaitu (1) merevisi penggunaan kata hubung pada teks deskripsi peristiwa, peserta didik akan mendata kesalahan penggunaan kata hubung yang ditemukan dari kutipan novel pada kolom tabel yang telah disediakan, dan (2) penyuntingan teman sejawat untuk menyempurnakan teks deskripsi peristiwa, peserta didik akan menilai hasil teks deskripsi tokoh teman sejawat. Kegiatan ini dilakukan dengan menukarkan hasil menulis teks deskripsi tokoh dengan teman sebangku, kemudian peserta didik akan menilai hasil teks deskripsi temannya sesuai dengan rubrik yang telah disediakan. 


\section{SIMPULAN}

Berdasarkan analisis penelitian Pengembangan Bahan Ajar Menulis Teks Deskripsi dengan Menggunakan Novel Tetralogi Laskar Pelangi untuk Siswa SMP Kelas VII dapat disimpulkan bahwa produk yang dikembang memiliki tiga unit. Unit I mendeskripsikan latar dalam novel dengan tiga bagian, yakni (1) membaca teks deskripsi latar dalam novel yang terdiri dari dua kegiatan antara lain membaca pemahaman untuk menentukan isi serta membaca pemahaman untuk mengenali kalimat utama dan kalimat penjelas, (2) menulis teks deskripsi latar, yang terdiri dari kegiatan, yaitu (a) mendeskripsikan bentuk atau wujud, (b) mendeskripsikan suasana objek dan waktu, dan (c) menulis teks deskripsi latar, dan (3) merevisi teks deskripsi latar dalam novel, yang terdiri dari dua kegiatan antara lain merevisi penggunaan kata awalan dan kata depan serta penyuntingan teman sejawat untuk menyempurnakan teks deskripsi latar.

Unit III mendeskripsikan tokoh dalam novel dengan tiga bagian, yakni (1) membaca teks deskripsi tokoh dalam novel yang terdiri dari dua kegiatan antara lain membaca pemahaman untuk menentukan isi serta membaca pemahaman untuk mengenali bentuk baku dan nonbaku, (2) menulis teks deskripsi tokoh, yang terdiri dari kegiatan, yaitu (a) mendeskripsikan perincian fisik tokoh, (b) mendeskripsikan perincian watak tokoh, (c) mendeskripsikan perincian peran dan bakat tokoh, dan (d) menulis teks deskripsi tokoh, dan (3) merevisi teks deskripsi tokoh dalam novel, yang terdiri dari dua kegiatan antara lain merevisi penggunaan huruf kapital serta penyuntingan teman sejawat untuk menyempurnakan teks deskripsi latar.

Unit III mendeskripsikan peristiwa dalam novel dengan tiga bagian, yakni (1) membaca teks deskripsi peristiwa dalam novel yang terdiri dari dua kegiatan antara lain membaca pemahaman untuk menentukan isi serta membaca untuk menceritakan kembali, (2) menulis teks deskripsi peristiwa, yang terdiri dari kegiatan, yaitu (a) mendeskripsikan perincian aktivitas suatu peristiwa, (b) mendeskripsikan perincian konflik dan solusi suatu peristiwa, dan (c) menulis teks deskripsi peristiwa, dan (3) merevisi teks deskripsi peristiwa dalam novel, yang terdiri dari dua kegiatan antara lain merevisi penggunaan kata kata hubung dan penyuntingan teman sejawat untuk menyempurnakan teks deskripsi peristiwa.

Bahan ajar ini dapat dimanfaatkan oleh guru bahasa Indonesia sebagai acuan dalam mengajarkan materi teks deskripsi. Bahan ajar ini juga dapat dijadikan sebagai rujukan dalam menghasilkan yang bervariasi. Di samping itu, bahan ajar ini dapat dijadikan suplemen pelengkap buku induk atau buku paket yang berasal dari pemerintah dalam pembelajaran. Produk bahan ajar yang dihasilkan telah diujicobakan pada kelas VII-C SMP Negeri 1 Bangil. Produk ini dapat digunakan oleh seluruh kelas VII SMP karena produk ini dikembangkan sesuai dengan tingkat berpikir siswa.

Saran ditujukan kepada peneliti lanjutan terdiri dari dua saran, yaitu (1) pemilihan jenis teks. Bahan ajar dikembangkan untuk pembelajaran menulis teks deskripsi, sebaiknya peneliti lanjutan mengembangkan jenis teks lain yang terdapat dalam kurikulum dan (2) sumber novel tetralogi Laskar Pelangi dalam bahan ajar. Sebaiknya peneliti menggunakan tema yang berbeda atau menggunakan judul novel yang berbeda.

\section{DAFTAR RUJUKAN}

Aminuddin. (2014). Pengantar Apresiasi Karya Sastra. Bandung: Sinar Baru Algensindo.

Atkinson, D. (2018). Theory in Second Language Writing. The TESOL Encyclopedia of English Language Teaching, (1), 1-6. https://doi.org/10.1002/9781118784235.eelt0524

Atmazaki., Afnita., \& Zuve, F. O. (2016). Pengembangan Bahan Ajar Membaca Berbasis Konteks. Seminar Nasional Pendidikan Indonesia, 1(1), 55-68.

Balmer, B. (2018). Deeper Understanding through Novels and Biographies. Consensus, 39(1), 6.

Durukan, E. (2011). Effects of Cooperative Integrated Reading and Composition (CIRC) Technique on Reading-Writing Skills. Educational Research and Reviews, 6(1), 102-109.

Graham, S. (2018). Introduction to Conceptualizing Writing. Educational Psychologist, 53(4), 217-219. https://doi.org/10.1080/00461520.2018.1514303

John, P. (2018). Constructivism: Its Implications for Language Teaching and Second-Language Acquisition.

Kristyanawati, M. D., Suwandi, S., \& Rohmadi, M. (2019). Peningkatan Keterampilan Menulis Teks Eksposisi menggunakan Model Problem Based Learning. Scholaria: Jurnal Pendidikan dan Kebudayaan, 9(2), 192-202. https://doi.org/10.24246/j.js.2019.v9.i2.p192-202

Lestari, W. D. (2017). Pengembangan Media Pembelajaran Menulis Teks Deskripsi Siswa Kelas VII SMP Negeri 12. Nosi, 5(2), 234-244.

Maryani, N., Ichsan, M., \& Khairunnisa. (2017). Signifikansi Metode Guide Reading Terhadap Motivasi Belajar Siswa Dalam Teori Membaca Nyaring Guide Reading Method on Students' Learning Motivation In Reading Loudly Lesson. Didaktika Tauhidi: Jurnal Pendidikan Guru Sekolah Dasar, 4(2), 126-139. https://doi.org/http://dx.doi.org/10.30997/dt.v4i2.924

Salfia, N. (2015). Nilai Moral Dalam Novel 5 CM Karya Donny Dhirgantoro. Jurnal Humanika, 3(15), 2-18.

Pannen, P. (2001). Kontruktivisme dalam Pembelajaran. Jakarta: Depdiknas.

Perfetti, C., \& Stafura, J. (2014). Word Knowledge in a Theory of Reading Comprehension. Scientific Studies of Reading, 18(1), 22-37. https://doi.org/10.1080/10888438.2013.827687 
Rasmianti., Bukhari., \& Yamin, M. (2017). Perbedaan Kemampuan Siswa Menulis Karangan Deskripsi menggunakan Media Lingkungan Rumah Siswa dan Tanpa Media Lingkungan Rumah Siswa di Kelas V SD Negeri Lamreung Aceh Besar. Jurnal Ilmiah Pendidikan Guru Sekolah Dasar, 2(2), 65-83.

Rosidi, I. (2009). Menulis Siapa Takut?. Yogyakarta: Kanisius.

Saddhono, K., Intan Pitaloka, R., Devilito, R., Mulyaningsih, I., Ketut Sudarsana, I., Isnaniah, S., ... Septiana, H. (2018). Relationship between Effective Sentence Understanding and Achievement Motivation with Description Text Writing Skill on Google Classroom. International Journal of Engineering \& Technology, 7(2.13), 432. https://doi.org/10.14419/ijet.v7i2.13.18134

Sari, I. P. (2018). Pengembangan Bahan Ajar Struktur Teks Deskripsi Berbasis Kearifan Lokal Tempat Wisata di Lubuklinggau Siwa Kelas VII Mts Mazro'illah Lubuklinggau. Canadian Apparel, 22(3), 248-260. https://doi.org/10.4135/9781412983907.N1584

Sitohang, Y., Syahfitri, D., \& Siburian, P. (2019). Upaya Meningkatkan Keterampilanmenulis Teks Deskripsi menggunakan Model Pembelajaran Discovery Learning pada Siswa Kelas VII-C SMP Negeri 3 Pancur Batu Tahun Pelajaran $2018 / 2019$. Jurnal Darma Agung, 27(2), 942-948. DOI: http://dx.doi.org/10.46930/ojsuda.v27i2.266

Somadayo, S. (2011). Strategi dan Teknik Pembelajaran Membaca. Yogyakarta: Graha Ilmu.

Tarigan, H. G. (2013). Menulis sebagai Suatu Keterampilan Berbahasa. Bandung: Angkasa.

Thi Yen Phuong, N. (2018). Theory of Constructivism and the Orientation of Hanoi Retraining College for Teachers and Educational Managers in Building a Model of Constructive School in Vietnam. American Journal of Educational Research, 6(6), 703-709. https://doi.org/10.12691/education-6-6-18

Trianto. (2015). Mendesain Model Pembelajaran Inovatif, Progresif, dan Kontekstual. Jakarta: Prenadamedia Grup.

Widodo, S. A. (2017). Development of Teaching Materials Algebraic Equation to Improve Problem Solving. Infinity Journal, 6(1), 59. https://doi.org/10.22460/infinity.v6i1.239

Wulandari, D., Rosiana, A., \& Abidin, H. A. Z. (2019). The Development of Science Teaching Materials Based on Practicum in Applying Motion Energy Concept Topic. 303, 189-194. https://doi.org/10.2991/icpeopleunnes-18.2019.38

Yanti, C. S. (2015). Religiusitas Islam Dalam Novel Ratu yang Bersujud Karya Amrizal Mochamad Mahdavi. Jurnal Humanika, 3(15), 22-27. https://doi.org/10.2527/2004.8213_supplE162x 